\title{
The Effect of Debt to Equity Ratio and Return on Equity on Stock Return with Dividend Policy as Intervening Variables in Subsectors Property and Real Estate on Bei
}

\author{
Dina Nurhikmawaty*, Isnurhadi, Marlina Widiyanti \\ Faculty of Economics, Universitas Sriwijaya, Palembang, Indonesia \\ Email: nurhikmawatydina@ymail.com
}

How to cite this paper: Nurhikmawaty, D., Isnurhadi, \& Widiyanti, M. (2020). The Effect of Debt to Equity Ratio and Return on Equity on Stock Return with Dividend Policy as Intervening Variables in Subsectors Property and Real Estate on Bei. Open Journal of Business and Management, 8 , 2148-2161.

https://doi.org/10.4236/ojbm.2020.85131

Received: August 8, 2020

Accepted: September 1, 2020

Published: September 4, 2020

Copyright $\odot 2020$ by author(s) and Scientific Research Publishing Inc. This work is licensed under the Creative Commons Attribution International License (CC BY 4.0).

http://creativecommons.org/licenses/by/4.0/

\begin{abstract}
The aims of this study are to investigate the effect of Debt to Equity Ratio and Return on Equity on stock returns with dividend policy as an intervening variable on the property and real estate companies in Indonesia. We collected annual data for eighteen property and real estate companies in Indonesia from the Indonesia Stock Exchange over the period of 2014-2018. We applied multiple linear regression model using SPSS and the Sobel test. Our analysis results found that Debt to Equity Ratio (DER), Return on Equity (ROE), and Dividend Payout Ratio (DPR) have a positive and significant affect on stock returns, both partially nor jointly. Furthermore, the result of Sobel test revealed Dividend Payout ratio (DPR) can be mediate the relationship of Debt to Equity Ratio (DER) and and Return on Equity (ROE) on stock returns. Based on these findings, we concluded that Debt to Equity Ratio (DER) and Return on Equity (ROE) have direct and indirect effects on Stock Return in 18 Indonesia's property and real estate companies.
\end{abstract}

\section{Keywords}

Debt to Equity Ratio, Return on Equity, Stock Returns, Dividend Payout Ratio, Dividend Policy

\section{Introduction}

Economic development at this time resulted in increasingly fierce business competition. For that, every company must be more leverage and always be more careful in running the company to obtain the profit (Thaib et al., 2020). A 
company, however, may evaluate the type and level of risk before it is adopted as a necessary condition in business operations (Nugraha et al., 2019). As the economy grows, the property and real estate industries also develop. At present, the profits earned by property companies listed on the Indonesia Stock Exchange (IDX) are experiencing a decline in aspects of their financial statements. This resulted in a lot of impacts experienced by the company. This is caused by various factors that occur. However, property companies listed on the IDX still make the best contribution to consumers. The decline in several aspects of financial statements experienced by property companies due to the impact of the existing global financial crisis. There is also a depreciation in the rupiah and an increase in fuel prices, which has caused uncertainty and rising inflation. This has resulted in doubts and delays in investing in the private sector and eroding national economic resilience (Pratiwi, 2018).

Research in the property sector is said to be important because the need for boards is one of the basic human needs. Activities in the property industry can be used as an indicator of how active economic activity is taking place (Utami, 2017). Every economic activity basically will always require property products as a factor of production. The development of property activities has a multiplier effect on the development of other sectors that are directly or indirectly related (Marzuki \& Newell, 2019). In the case, if there is no demand for property products, it indicates that the economy is in an underdeveloped condition. Property is arguably the sector that never dies. When other sectors collapsed due to economic crisis, the property business showed an anomaly. In various places, there are houses and shophouses, apartments, shopping centers, office centers, condominiums and housing (Pratiwi, 2018).

The motivation of investors investing in the capital market is to get a return. Stock return is the level of income obtained by subtracting the current closing price from the previous stock closing price divided by the previous year's closing price (Khadafi et al., 2014). Therefore, investors need an assessment of the company's financial performance before investing capital in that company. The performance appraisal of a company can be done by analyzing the company's financial ratios. Financial ratio analysis is conducted to determine the strengths and weaknesses of company's financial performance (Santosa, 2016). These financial ratios provide information about the short-term and long-term opportunities on a company's. Debt to Equity Ratio (DER) and Return on Equity (ROE) are two important indicators that investors generally use in assessing the performance of a company. Furthermore, Debt to Equity Ratio (DER) and Return on Equity (ROE) are considered to have an important role in dividend policy, where this policy can ultimately maximize stock returns.

According to Lesakova (2007), profitability ratio is ratio intended to measure the effectiveness of management that is reflected in return for the investment result through the company's activities or in other words, measuring the company's overall performance and efficiency in the management of liabilities and 
capital. Return on Equity (ROE) is included in the profitability ratio. According to Komala and Nugroho (2013), one of the main reasons operate the company is to generate profit that will be beneficial for shareholders. The success Measures of achievement of this reason is the number of ROE. Meanwhile, Debt to Equity Ratio (DER) is one of the solvency ratios. According to Khadafi et al. (2014), Debt to Equity Ratio (DER) is a ratio used to assess the debt to equity by comparing the entire debt, including current liabilities with the overall of equity. DER for every company is different, depending on the characteristics of business and the diversity of cash flow.

Study related the determinant factors that influence stock returns and dividend policy have been widely studied by academics, but no studies have investigated this issue on the property sector in Indonesia. Based on the background and problem formulations that have been described previously, the purpose of this study is to analyze the effect of Debt Equity Ratio (DER) and Return On Equity (ROE) on stock returns in the property and real estate companies that listed on the Indonesia Stock Exchange (IDX) over the period of 2014-2018. Furthermore, this study also aims to examine whether Dividend Policy can mediate the relationship of Return on Equity and Debt Equity Ratio on stock returns in the property and real estate companies in Indonesia. This research is expected to be used as a reference by the property company managers in Indonesia to improve their future financial performance and also can be used by shareholders as considerations before making investment decisions to the Indonesia's property companies in the capital market.

\section{Literature Review}

\subsection{The Effect of Debt to Equity Ratio (DER) on Stock Returns}

According to Horne and Wachowicz (2005), Debt to Equity Ratio is a comparison between total debt or total debts with total shareholder's equity. This ratio is sought by comparing all debt, including current debt and all equity. For banks (creditors), the greater this ratio, the more unprofitable because the greater the risk borne by the failure that may occur in the company. The company's ability to pay debts funded by its own capital can be measured using Debt to Equity Ratio (DER). DER is a ratio that reflected the share of own capital that is used as collateral for all debts (Khadafi et al., 2014). The higher of DER indicates the high capital dependence of company's toward outsiders so that the company's interest expenses would be heavier (Izuddin, 2020). It is certainly would reduce the rights of the company's shareholders because the rate of return is getting smaller. Moreover, the higher of DER caused the greater the company's liabilities compared to the company's own equity. The higher of DER tends to decrease stock return because the high level of debts indicates the company's burden and certainly reducing profits. In other words, DER did not have significant effects on stock returns. Study by Nurmasari (2017) and Siburian (2013) also found that DER did not influence stock return. 
$\mathrm{H}_{1}$ : Debt to Equity Ratio did not have significant effects on Stock Return.

\subsection{The Effect of Return on Equity (ROE) on Stock Returns}

Return on Equity (ROE) is the rate of return that achieved by the company for each currency unit that further becomes the company's capital. According to Brigham and Houston (2012), the notion of ROE is the net ratio of ordinary equity measures the rate of return on ordinary shareholder investment. This Return on Equity Ratio shows the efficient use of own capital. If this ratio is higher, the better. That means the company's position will be stronger, and vice versa. Return on Equity is calculated by dividing net income with shareholder equity. In this context, how large the company provides yield every year per one currency that investing by the company investors (Tang, 2016). ROE is a measure of the return that achieved by investors from his investment in a company. The higher results lead to better the stock return. According to Berggrun et al. (2020), profitability affects stock returns. Return on Equity (ROE) is a measure of a company's ability to generate profits using their own capital. The increasing ROE value indicates the company's performance is getting better. Conditions like this will be a special attraction for the old investors to keep investing their shares and potential investors to investment in the company (Brigham \& Houston, 2012). This condition will encourage an increase in stock prices which in turn will increase stock returns. Based on previous studies, Susilowati and Turyanto (2011) and Aziz (2012) found that ROE has a positive and significant effect on stock returns

$\mathrm{H}_{2}$ : Return On Equity has a positif and significant effects on Stock Return.

\subsection{The Effect of Debt to Equity Ratio (DER) on Devidend Payout Ratio (DPR)}

Dividend is the distribution of profits/profits made by a company to shareholders on the profits obtained by the company (Halim, 2015). Whereas dividend policy is a decision to divide the profits obtained by the company to shareholders as dividends or will retain in the form of retained earnings to be used as investment financing in the future. If the company chooses to distribute profits as dividends, it will reduce retained earnings and then reduce the total source of internal funding or internal financing. Conversely, if the company chooses to hold the profits obtained, then the ability to form internal funds will be even greater (Sartono, 2014). According to Syamsudin (2011) Dividend payments differ from interest payments because dividends cannot reduce the amount of taxes paid by companies, because the funds are taken from net income after taxes (earning after taxes). Dividend payout ratio measurement is a part that is integrated with the company's funding decision. Dividend Payout Ratio, which is the ratio that shows the results of the comparison between cash dividends per share and earnings per share.

Pilbeam (2010: p. 224) stated that the greater DER of a firm will encourage the 
more of a firm's earnings have to be devoted to interest payment of the firm's debt, and consequently less money is available for shareholders. It indicates that the higher level of DER leads to the composition of debt is also higher and certainly reflected a lower ability of firms' to pay dividends (Gill et al., 2010). This condition encourages the company has to pay its obligations instead of distributing its profits in the form of dividends. Moreover, if the debt to equity value of the company is high, it indicates that the dividend payout ratio distributed by the company is not as expected by investors. Study by Marlina and Danica (2009) proved that debt to equity ratio did not have a significant effect on dividend payout ratio. The higher this ratio, the bigger the obligations and the lower the ratio as well as encourage the company's ability to fulfill their obligations. The increase in debt owned by the company will affect the size of the company's net income available to shareholders, including the distribution of the dividend payout ratio.

$\mathrm{H}_{3}$ : Debt to Equity Ratio did not have significant effects on Devidend Payout Ratio.

\subsection{The Effect of Return on Equity (ROE) on Devidend Payout Ratio (DPR)}

Study by Carlo (2014) and Hanif and Bustamam (2017) found that ROE has a positive and significant effect on the DPR. This means that if ROE increases, the DPR will also increase. Conversely, if ROE has decreased, the DPR will also experience a decline. ROE is a profitability ratio that describes the company's ability to generate net profit after tax using its own capital. The higher of ROE reflected the higher level of profit that obtained by the company owner. The high profit level of company owners will encourage to increase the company's ability to pay dividends. Based on the smoothing theory (Lintner, 1956), the size of the dividend depends on the company's current profits and previous dividends. Based on this theory, the higher of profit lead to the higher of portion profits that share as dividends.

$\mathrm{H}_{4}$ : Return On Equity (ROE) has a positive and significant effect on Dividend Payout Ratio.

\subsection{Dividend Payout Ratio (DPR) Mediate the Effect of Debt to Equity Ratio (DER) on Stock Returns}

The results of previous research conducted by Annisa and Chabachib (2017) found that DER has a significant effect on stock returns with dividends as the mediating variable. A company with a low DER means that it has a low level of debt as well, a low level of debt is considered to be able to increase the company's earnings, if the company's income increases, the dividends distributed will also increase, this dividend increase will also have an impact on increasing stock returns (Santosa, 2016). An increase or decrease in debt will in turn affect the size of net income that obtained to shareholders, including dividends received, 
because the obligation to pay debt takes precedence than pay dividends. Thus, the lower of debt ratio indicates the higher of profitability ratio on a company's. With the increasing profitability, the company will increase their ability to pay dividends (Brigham \& Houston, 2012). In accordance with the signaling hypothesis theory, it can be stated that a lower DER indicates that the company will have increased revenue, so this is good news or a good signal for investors and will have an impact on increasing dividends paid, so that it will also increase their stock return.

$\mathrm{H}_{5}$ : Dividend Payout Ratio (DPR) mediates the effect of Debt to Equity Ratio on Stock Return.

\subsection{Dividend Payout Ratio (DPR) Mediate the Effect of Return on Equity (ROE) on Stock Returns}

A company with a high Return on Equity (ROE) shows that they have sufficient profit to pay dividends to their shareholders. The higher of ROE value shows that the higher of dividends distributed to shareholders and directly shows stock return also will increase. Dividend policy provides information about the company's future profit growth, this information will invite responses from investors which will affect the company's returns (Baah et al., 2014). In accordance with the signaling hypothesis theory, it can be stated that a higher ROE indicates that the company has high profits, so this becomes good news or a good signal for investors and will have an impact on increasing dividends paid, so that it will also increase its stock returns. The results of previous research that conducted by Santosa (2016) and Nareshwari (2016) found that profitability ratio that reflected by ROE value has a significant effect on stock returns with DPR as a mediating variable.

$\mathrm{H}_{6}$ : Dividend Payout Ratio (DPR) mediates the effect of Return On Equity on Stock Return.

\section{Research Method}

\subsection{Data}

Data that used in this study is secondary data that obtained online from the Indonesia Stock Exchange (IDX) website. We collecting annual data of Debt Equity Ratio (DER), Return On Equity (ROE), Dividend Payout Ratio (DPR) and Stock Return (SR) over the period of 2014-2018 from the financial statement and annual report of the property and real estate companies in Indonesia. Total Real Estate and Property companies listed on the Indonesia Stock Exchange (IDX) are 54 companies, but only annual data for 18 companies that available for the period of 2014-2018. Therefore, in this study we only use annual data of 18 Real Estate and Property companies in Indonesia.

\subsection{Analysis Method}

The data analysis method used in this study uses multiple linear regression with 
the help of the SPSS (Statistical Product and Service Solutions program) program. Based on the hypothesis in this study, the data analysis method used is quantitative analysis to calculate or estimate quantitatively from several factors individually or together with the related variables. The functional relationship between one variable related to the independent variable can be done with multiple linear regression. The research framework is the relationship between one indicator to another indicator that studied. For this framework to connect and explain a topic to be discussed. This flow of thought is expected to provide direction and an overview of the variables to be examined. The variables that will be used in analyzing stock returns are financial ratios that include Debt to Equity Ratio and Return on Equity. The research framework in study can be described as follows (Figure 1).

Based on research framework above, we then develop two-equation models as follows:

$$
\begin{gathered}
\mathrm{DPR}=\alpha+\beta_{1} \mathrm{DER}+\beta_{2} \mathrm{ROE}+\varepsilon \\
\mathrm{SR}=\alpha+\beta_{1} \mathrm{DER}+\beta_{2} \mathrm{ROE}+\beta_{3} \mathrm{DPR}+\varepsilon
\end{gathered}
$$

where, $\alpha$ is constanta; $\beta_{i}(i=1,2,3)$ are the coefficients of independent variables; and $\varepsilon$ is error term. Equation (1) uses to estimate the effect of Debt to Equity Ratio (DER) and Return on Equity (ROE) on Dividend Payout Ratio (DPR), while Equation (2) uses to estimate the effect of Debt to Equity Ratio (DER) and Return on Equity (ROE), and Dividend Payout Ratio (DPR) on Stock Return (SR).

According to (Hakimah et al., 2019), a mediating/intervening variable influences the relationship between the independent variables dan the dependent variable. In this study, Dividend Payout Ratio (DPR) determined as a mediating/intervening variable that expected to improve the impact of Debt to Equity Ratio (DER) and Return on Equity (ROE) on Stock Return (SR). Furthermore, in order to examine the effect of mediating/intervening variable, we applied Sobel test that developed by Sobel $(1982,1986)$. The formula of the Sobel test can be written as follows:

$$
S_{a b}=\sqrt{b^{2} S_{a}^{2}+a^{2} S_{b}^{2}+S_{a}^{2} S_{b}^{2}}
$$

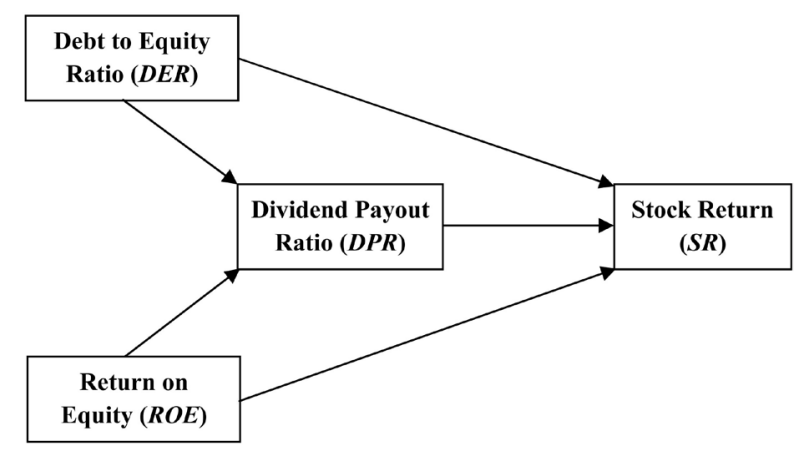

Figure 1. Research framework. 
where $S_{a b}$ is the standard error of indirect effect; $S_{a}$ is the standard error of coefficient $a ; S_{b}$ is the standard error of coefficient $b ; a$ is the coefficient of Debt to Equity Ratio (DER) and Return on Equity (ROE) toward Dividend Payout Ratio (DPR) in model 1, respectively; $b$ is the coefficient of Dividend Payout Ratio (DPR) toward Stock Return (SR) in model 2. Meanwhile, the significance of indirect effect between each independent variables toward the dependent variable through mediating/intervening variable determines using formula as follows:

$$
t_{\text {count }}=\frac{a b}{S_{a b}}
$$

Futhermore, the value of $t_{\text {count }}$ will compare with the value of $t_{\text {table }}$ (i.e. 1.96). We concluded existence of indirect effect if the value of $t_{\text {count }}$ higher than the value of $t_{\text {table }}$ and rejected existence of indirect effect if the value of $t_{\text {count }}$ lower than the value of $t_{\text {table. }}$

\section{Results}

Table 1 reports the result of estimation model 1. It can be seen that the coefficients of Debt to equity Ratio (DER) and Return on Equity (ROE) are positive and statistically significant influences Dividend Payout Ratio (DPR). First, this result shows that a rise $1 \%$ of Debt to equity Ratio (DER) will cause Dividend Payout Ratio (DPR) increases $0.38 \%$, vice versa. This result similar as finding by Rehman \& Takumi (2012) which also found a positive effect Debt to Equity Ratio on Dividend Payout Ratio, but contrary with finding by Komrattanapanya and Suntraruk (2013), Labhane and Das (2015), as well as Yasa and Wirawati (2016) who found that Debt to Equity Ratio has a negative effect on Dividend Payout Ratio (DPR).

Second, our result shows that a rise 1\% of Return on Equity (ROE) will cause Dividend Payout Ratio (DPR) increases $0.66 \%$. The findings similar as study by Komala and Nugroho (2013), Sumampow and Murni (2016), Kartika (2015), Yudiana and Yadnyana (2016), as well as Yasa \& Wirawati (2016) which also found that Return on Equity (ROE) has a significant positive effect to Dividend Payout Ratio (DPR). Nevertheless, there findings contrast with study by Komala and Nugroho (2013) and Maladjian and Khoury (2014) who found a negative effect Return on Equity (ROE) on Dividend Payout Ratio (DPR).

Table 1 . The result of equation model 1 .

\begin{tabular}{ccccc}
\hline Regressors & Coefficient & Standard Error & t-statistics & F-statistics \\
\hline Constanta & 5.196 & 0.417 & $12.450^{\star * *}$ & \\
LN_DER & 0.381 & 0.154 & $2.468^{\star *}$ & $11.369^{\star * *}$ \\
LN_ROE & 0.656 & 0.164 & $3.994^{* * *}$ & \\
R-squares & & 0.207 & DW-statistics & 2.283 \\
\hline
\end{tabular}

Note: ${ }^{* *}$ and ${ }^{* * *}$ denotes significant at $5 \%$ and $1 \%$ levels, respectively. 
The value of F-statistics shows that Debt to equity Ratio (DER) and Return on Equity (ROE) jointly significant influences Dividend Payout Ratio (DPR). The value of R-square indicated that the capability of all independent variables to interpreting the change of dependent variable is only $20 \%$, while the rest is influences by other indicators that not accounted on the equation models. Meanwhile, the value of Durbin-Watson statistics indicated there is no serial correction issue in the equation model 1.

Table 2 reports the result of estimation model 2. It can be seen that the coefficients of Debt to equity Ratio (DER), Return on Equity (ROE) and Dividend Payout Ratio (DPR) are positive and statistically significant influences Stock Return (SR). First, our result shows that a rise $1 \%$ of Debt to equity Ratio (DER) will cause Stock Return (SR) increases $0.24 \%$. This finding indicates that higher the value of DER, the more equity funding through debt. It implies that the capital structure of the business more use of debts. The increase in DER can also be caused by the value of own capital is much smaller when compared to debt on external parties. Increasing the use of debt will increase company capital but if the company is unable to manage these funds effectively and efficiently, so a high debt equity ratio will reflect the high debt held by the company. If the company's Debt to Equity Ratio (DER) is high, there is a possibility that the company's stock price will be low because if the company makes a profit, the company tends to use that profit to pay its debt compared to dividing the dividend. Nevertheless, our findings opposite with findings by Nurmasari (2017) who found that DER did not any effect on Stock Return (SR).

Second, our result found that a rise $1 \%$ of Return on Equity (ROE) will cause Stock Return (SR) increases $0.63 \%$. These results indicate an increase and decrease in stock returns will be influenced by Return on Equity information. This ratio illustrates the rate of return on own capital in generating net income. If the Property and Real Estate company shows an increase in ROE, then the company has good management in managing its capital optimally to generate net profit. So that it can improve the welfare and trust of investors who invest their capital in the Property and Real Estate company. Investor confidence will be followed by increased demand for these shares. Then the request will be followed by a rising stock price and then the stock return that will be obtained will also increase.

Table 2. The result of equation model 2.

\begin{tabular}{ccccc}
\hline Regressors & Coefficient & Standard Error & t-statistics & F-statistics \\
\hline Constanta & 0.920 & 0.529 & $1.739^{*}$ & \\
LN_DER & 0.236 & 0.121 & $1.949^{*}$ & $41.739^{\star * *}$ \\
LN_ROE & 0.632 & 0.136 & $4.656^{* * *}$ & \\
LN_DPR & 0.549 & 0.081 & $6.740^{* * *}$ & 1.821 \\
R-squares & & 0.593 & DW-statistics \\
\hline
\end{tabular}

Note: ${ }^{* *},{ }^{* *},{ }^{*}$ denotes significant at $1 \%, 5 \%$ and $10 \%$ levels, respectively. 
The positive influence between Return on Equity on stock returns, shows that investors use ROE contained in the issuer's financial statements as an analysis tool to obtain a decent stock return. The results of this study support the research conducted by Aziz (2012) and Susilowaty (2011) who also found that Return On Equity has a positive and significant effect on stock returns.

Third, our result indicates that a rise $1 \%$ of Dividend Payout Ratio (DPR) will cause Stock Return (SR) increases $0.55 \%$. This finding similar as study by Rehman \& Takumi (2012) who also found that a rise in Debt to equity ratio (DER) will caused Dividend Payout Ratio (DPR) also increased. The value of F-statistics shows that Debt to equity Ratio (DER), Return on Equity (ROE) and Dividend Payout Ratio (DPR) jointly significant influences Stock Return (SR). The value of R-square indicated that the capability of all independent variables to interpreting the change of dependent variable is only $59 \%$, while the rest is influences by other indicators that not accounted on the equation models. Meanwhile, the value of Durbin-Watson statistics indicated there is no serial correction issue in the equation model 1.

The result of Sobel test for estimates the indirect effect of Debt to equity Ratio (DER) on Stock Return (SR) through Dividend Payout Ratio (DPR) as mediating variable is as follows:

$$
\begin{gathered}
S_{a b}=\sqrt{b^{2} S_{a}^{2}+a^{2} S_{b}^{2}+S_{a}^{2} S_{b}^{2}} \\
S_{a b}=\sqrt{\left(0.549^{2} \times 0.154^{2}\right)+\left(0.380^{2} \times 0.081^{2}\right)+\left(0.154^{2} \times 0.081^{2}\right)} \\
S_{a b}=0.091
\end{gathered}
$$

Then, the value of $t_{\text {count }}$ obtaining as follows:

$$
t_{\text {count }}=\frac{a b}{S_{a b}}=\frac{0.380 \times 0,549}{0.090835209}=\frac{0.20862}{0.09083}=2.297
$$

The value of $t_{\text {count }}$ (2.297) greater than $t_{\text {count }}(1.96)$. Therefore, it can be concluded that there is an indirect effect running from Debt to equity Ratio (DER) to Stock Return (SR) through Dividend Payout Ratio (DPR). this finding indicates that a company with a low DER has a low debt level as well, a low debt level is considered to be able to increase the company's revenue, if the company's revenue increases, the dividends distributed will also increase, this increase in dividends will also have an impact on increasing stock returns. An increase or decrease in debt will in turn affect the size of the net profit available to par shareholders including dividends received because the obligation to pay debts takes precedence over dividend distribution. Thus the lower the debt ratio will further increase the profitability ratio of a company. The results of this research that support this research conducted by Nazir et al. (2012) who stated that there is an influence of leverage ratio (DER) on stock returns with dividends as a mediating variable.

The result of Sobel test for estimates the indirect effect of Return On Equity (ROE) on Stock Returns through Dividend Payout Ratio (DPR) as mediating 
variable is as follows:

$$
\begin{gathered}
S_{a b}=\sqrt{b^{2} S_{a}^{2}+a^{2} S_{b}^{2}+S_{a}^{2} S_{b}^{2}} \\
S_{a b}=\sqrt{\left(0.549^{2} \times 0.164^{2}\right)+\left(0.656^{2} \times 0.081^{2}\right)+\left(0.164^{2} \times 0.081^{2}\right)} \\
S_{a b}=0.096
\end{gathered}
$$

Then, the value of $t_{\text {count }}$ obtaining as follows:

$$
t_{\text {count }}=\frac{a b}{S_{a b}}=\frac{0.656 \times 0.549}{0.096}=\frac{0.360}{0.096}=3.748
$$

From the results, the value of $t_{\text {count }}$ is 3.748 , it is greater than $t_{\text {table }}$ at $5 \%$ significant level (1.96). Based on this finding, it can be concluded that there is an indirect effect running from Return on Equity (ROE) to Stock Return (SR) through Dividend Payout Ratio (DPR). This finding implies that a company with a high Return on Equity (ROE) has enough profit to pay dividends to its shareholders. The higher ROE, the dividends distributed to shareholders will also be higher, so stock returns will also go up. Dividend policy provides information about the company's profit growth in the future, this information will invite a response from investors which in turn will affect the company's return (Baah et al., 2014). In accordance with the signaling hypothesis theory, it can be stated that the higher ROE shows that the company has a high profit as well, so this becomes good news or a good signal for investors and will have an impact on increasing dividends paid, thus also increasing stock returns. The result supported the study conducted by Rahmaninia (2016) who stated that there is an effect of the profitability ratio (ROE) on stock returns with dividends as a mediating variable.

\section{Conclusion}

Based on our study, we concluded that DER (Debt to Equity Ratio) and Return on Equity (roe) have significant effects to dividen payout ratio (dpr), while an increase or decrease in Stock Return (SR) influenced by DER (Debt to Equity Ratio), Return on Equity (ROE) and Dividen Payout ratio (DPR). Moreover, we also found that DPR (Dividen Payout ratio), as mediating variable, stimulates the effect of Debt to Equity Ratio (DER) and Return on Equity (ROE) toward Stock Return (SR) on the property and real estate companies in Indonesia. Based on these findings, we recommended companies to pay attention to the quality of the Debt to Equity ratio (DER) and Return on Equity (ROE) in the company in order to provide more benefit to the shareholders. Furthermore, investors who are interested in investing in stock securities should always pay attention to the company's financial and non-financial factors. One of them is by paying attention to solvency, profitability, stock returns, and dividend policy. This is because there are many factors that affect the return on investment. Investors who expect returns in the form of dividends should pay attention to the company's Return on Equity (ROE), because ROE has the greatest and most significant effect on the Dividend Payout Ratio (DPR). 
Overall, our results show that although theoretically not all variables affect stock returns, our research proves that DER, ROE, and DPR have a significant effect on stock returns. This is possible because of differences in objects, periods, samples used in the study. Nevertheless, our study has several limitations. First, we only consider the Debt to Equity Ratio (DER), Return on Equity (ROE) and Dividend Payout Ratio (DPR) as indicators that affect stock returns. Second, in our research we only collected annual data for eighteen property and real estate companies in Indonesia over the period of 2014-2018. Therefore, further studies are expected to consider other indicators as exogenous variables to investigate the factors that affect the company's stock returns. Moreover, we also suggest future studies to improve the number of samples and periods of data that use in the study for better results. Furthermore, this study is expected to be useful to enrich the concepts or theories that support the development of knowledge about financial management, especially study related to investment decisions, solvency ratios, profitability ratios, and dividend policies.

\section{Conflicts of Interest}

The authors declare no conflicts of interest regarding the publication of this paper.

\section{References}

Annisa, R., \& Chabachib, M. (2017). Analisis Pengaruh Current Ratio (Cr), Debt to Equity Ratio (Der), Return on Assets (Roa) Terhadap Price to Book Value (Pbv), Dengan Dividend Payout Ratio Sebagai Variabel Intervening. Diponegoro Journal of Management, 6, 188-202.

Aziz, N. S. (2012). Pengaruh Return on Assets (ROA), Debt to Equity Ratio (DER), Tingkat Suku Bunga dan Tingkat Inflasi terhadap Return Saham Sektor Perbankan di Bursa Efek Indonesia (Periode 2003-2010). Universitas Hasanuddin Makassar.

Baah, B. K., Tawiah, R., \& Opoku, F. E. (2014). Industry Sector Determinants of Dividend Policy and Its Effect on Share Prices in Ghana. International Journal of Economics, Business and Finance, 2, 1-19.

Berggrun, L., Cardona, E., \& Lizarzaburu, E. (2020). Firm Profitability and Expected Stock Returns: Evidence from Latin America. Research in International Business and Finance, 51, Article ID: 101119. https://doi.org/10.1016/j.ribaf.2019.101119

Brigham, E. F., \& Houston, J. F. (2012). Fundamentals of Financial Management. Boston, MA: Cengage Learning.

Carlo, M. A. (2014). Pengaruh Return on Equity, Dividend Payout Ratio, Dan Price to Earnings Ratio Pada Return Saham. E-Jurnal Akuntansi Universitas Udayana, 7, 150-164.

Gill, A., Biger, N., \& Tibrewala, R. (2010). Determinants of Dividend Payout Ratios: Evidence from United States. The Open Business Journal, 3, 8-14.

https://doi.org/10.2174/1874915101003010008

Hakimah, Y., Hildayanti, S. K., \& Nugraha, A. T. (2019). Influence of Economic Indicators on Supply Chain: Evidence from Indonesian Fishing Industry. International Journal of Supply Chain Management, 8, 854-863.

Halim, A. (2015). Manajemen Keuangan Bisnis: Konsep dan Aplikasinya. Jakarta: Mitra 
Wacana Media.

Hanif, M., \& Bustamam, B. (2017). Pengaruh Debt to Equity Ratio, Return on Asset, Firm Size, Dan Earning Pe Share Terhadap Dividend Payout Ratio (Studi pada Perusahaan Manufaktur yang Terdaftar di Bursa Efek Indonesia Tahun 2011-2015). Jurnal Ilmiah Mahasiswa Ekonomi Akuntansi, 2, 73-81. https://doi.org/10.24964/ja.v2i1.20

Izuddin, M. (2020). Analisis Pengaruh Faktor Fundamental Terhadap Return Saham Perusahaan Konstruksi (Studi Pada Saham Perusahaan Yang Tercatat Aktif Dalam LQ-45 di BEI Periode 2011-2018). Jurnal Ilmiah Ekbank, 3, 1-12. https://doi.org/10.12928/j.reksa.v3i1.27

Khadafi, M., Heikal, M., \& Ummah, A. (2014). Influence Analysis of Return on Assets (ROA), Return on Equity (ROE), Net Profit Margin (NPM), Debt to Equity Ratio (DER), and Current Ratio (CR), against Corporate Profit Growth in Automotive in Indonesia Stock Exchange. International Journal of Academic Research in Business and Social Sciences, 4, 219-226. https://doi.org/10.6007/IJARBSS/v4-i12/1331

Komala, L. A. P., \& Nugroho, P. I. (2013). Pengaruh Profitabilitas Rasio, Likuiditas, dan Hutang terhadap Investasi Kembali. Journal of Business and Economics, 4, 1176-1186.

Lesakova, L. (2007). Uses and Limitations of Profitability Ratio Analysis in Managerial Practice. In International Conference on Management, Enterprise and Benchmarking (pp. 1-2).

Lintner, J. (1956). Distribution of Incomes of Corporations. American Economic Review, $46,97-133$.

Marlina, L., \& Danica, C. (2009). Analisis Pengaruh Cash Position, Debt to Equity Ratio, Dan Return on Assets Terhadap Divident Payout Ratio. Jurnal Manajemen Bisnis, 2, $1-6$.

Marzuki, M. J., \& Newell, G. (2019). The Emergence of Data Centres as an Innovative alternative Property Sector. Journal of Property Investment \& Finance, 37, 140-152. https://doi.org/10.1108/JPIF-08-2018-0064

Nareshwari, N. (2016). Analisis Faktor yang Mempengaruhi Nilai Perusahaan dengan Dividend Payout Ratio sebagai Variabel Intervening (Studi pada Perusahaan Manufaktur yang Terdaftar di BEI Tahun 2011-2015). Kota Semarang: Diponegoro University.

Nazir, M. S., Abdullah, M. M. N., \& Nawaz, M. (2012). How Dividend Policy Affects Volatility of Stock Prices of Financial Sector Firms of Pakistan. EuroJournals Publishing Incorporation: American Journal of Scientific Research, 61, 132-139.

Nugraha, A. T., Fitri, H., Widiyanti, M., Guntoro, R., \& Sulastri (2019). The Role of the Risk Management Committee in Managing Supply Chain Risk and Enhancing Supply Chain Performance: An Emerging Market Perspective. International Journal of Supply Chain Management, 8, 319-327. http://excelingtech.co.uk

Nurmasari, I. (2017). Analisis Current Ratio, Return on Equity, Debt to Equity Ratio dan Pertumbuhan Pendapatan Berpengaruh Terhadap Return Saham Pada Perusahaan Pertambangan Di Bursa Efek Indonesia 2010-2014. Jurnal Kreatif, 5, 112-131.

Pilbeam, K. (2010). Finance \& Financial Markets (Third). London: Palgrave Macmillan. https://doi.org/10.1007/978-1-137-09043-0

Pratiwi, P. (2018). Pengaruh Struktur Kepemilikan Terhadap Nilai Perusahaan dengan Kebijakan Hutang sebagai Variabel Intervening (Studi Kasus Perusahaan Property dan Real Estate yang Terdaftar di Bursa Efek Indonesia). Universitas Islam Negeri Alauddin Makassar. https://doi.org/10.35448/jmb.v9i2.4232

Rahmaninia, E. (2016). An Assessment of the Forecast of Future Earnings and Its Impact 
on Financing through Retained Earnings Considering Payable Dividends in Pharmaceutical Companies Listed in Stock Exchange. International Journal of Humanities and Cultural Studies, 3, 1126-1134.

Rehman, A., \& Takumi, H. (2012). Determinants of Dividend Payout Ratio: Evidence from Karachi Stock Exchange (KSE). Journal of Contemporary Issues in Business Research, 1, 20-27.

Santosa, A. E. (2016). Analisis Pengaruh ROA, DER, CR, Firm Size, dan Sales Growth terhadap Nilai Perusahaan dengan Dividen Payout Ratio sebagai Variabel Mediator (Studi Pada Perusahaan Non Financial yang Terdaftar Di BEI Tahun 2010-2014). Kota Semarang: Diponegoro University.

Sartono, A. (2014). Manajemen Keuangan: Teori dan Aplikasi (4th ed.). Yogyakarta: BPFE.

Siburian, F. E. (2013). Analisis Pengaruh DER, ROA Terhadap Return Saham pada Perusahaan Perbankan yang Terdaftar di BEI. Jurnal Ekonomi \& Keuangan, 1, 25-32.

Sobel, M. E. (1982). Asymptotic Confidence Intervals for Indirect Effects in Structural Equation Models. Sociological Methodology, 13, 290. https://doi.org/10.2307/270723

Sobel, M. E. (1986). Some New Results on Indirect Effects and Their Standard Errors in Covariance Structure Models. Sociological Methodology, 16, 159. https://doi.org/10.2307/270922

Susilowati, Y., \& Turyanto, T. (2011). Reaksi Signal Rasio profitabilitas dan rasio solvabilitas terhadap return saham perusahaan. Dinamika Keuangan Dan Perbankan, 3, 17-37.

Syamsudin, L. (2011). Manajemen Keuangan Perusahaan. Jakarta: Raja Grafindo Persada.

Tang, A. Y. Y. (2016). Can Stock Visibility or Neglected-Firm Effect Help Explain the Outperformance of HK-Listed Mainland Companies? Open Access Theses and Dissertations, Hong Kong: Hong Kong Baptist University.

Thaib, D., Hakimah, Y., \& Yolanda (2020). The International Trade, Foreign Direct Investment and Economic Growth: ASEAN Perspective. International Journal of Innovation, Creativity and Change, 11, 42-62.

Utami, E. S. (2017). The Effect of the Crisis on Financial Performance of Property Sector in Indonesia. Investment Management and Financial Innovations, 14, 248-253. https://doi.org/10.21511/imfi.14(1-1).2017.11

Van Horne, J. C., \& Wachowicz, J. M. (2005). Fundamentals of Financial Management. London: Pearson Education. 